\title{
Novel analogs of ghrelin: physiological and clinical implications
}

Heather A Halem, John E Taylor, Jesse Z Dong, Yeelana Shen, Rakesh Datta, Alfonso Abizaid ${ }^{1}$, Sabrina Diano ${ }^{1}$, Tamas Horvath $^{1}$, Philippe Zizzari ${ }^{2}$, Marie-Thèrèse Bluet-Pajot ${ }^{2}$, Jacques Epelbaum ${ }^{2}$ and Michael D Culler

IPSEN, 27 Maple Street, Milford, Massachusetts 01757, USA, ${ }^{1}$ Reproductive Neuroscience Unit, Department of Obstetrics and Gynecology and Department of Neurobiology, Yale Medical School, New Haven, Connecticut, USA, and ${ }^{2}$ INSERM U549, Centre Paul Broca, Paris, France

(Correspondence should be addressed to M D Culler; Email: michael.culler@ipsen.com)

\begin{abstract}
Ghrelin, the 28 amino acid peptide recently identified as the natural ligand for the growth hormone (GH) secretagogue (GHS) receptor, has multiple activities in addition to stimulation of GH secretion, including stimulation of feeding and weight gain. To utilize these actions for potential therapeutic benefit, we have produced analogs of human ghrelin with enhanced metabolic stability, affinity for the GHS receptor, and efficacy in stimulating weight gain. We have also discovered an analog of ghrelin, BIM-28163, that is an antagonist at the GHS receptor and that fully inhibits GHS receptor activation induced by native ghrelin. In vivo, BIM-28163 does not increase GH secretion but fully blocks ghrelin-induced GH secretion. In contrast, BIM-28163 acts as a full agonist with regard to the ghrelin actions of stimulating weight gain and food intake. These results suggest that a receptor other than the GHS receptor mediates the actions of ghrelin on feeding and weight gain. This concept is strengthened by our observation that at certain hypothalamic sites, BIM-28163 acts as an antagonist of ghrelin-induced neuronal activation, while at other sites, both ghrelin and BIM-28163 induce neuronal activation via the same receptor. Collectively, these results indicate the existence of a novel ghrelin receptor that may regulate the feeding activity of ghrelin. Using BIM-28163 as a tool to define the endogenous role of ghrelin in normal GH secretion, we have demonstrated that antagonism of the GHS receptor in normal rats does not impair the pulsatility of GH secretion but lowers the pulse amplitude and mean GH level. These results demonstrate that endogenous ghrelin acts to amplify the basic pattern of GH secretion established by the interplay of hypothalamic GH-releasing hormone and somatostatin. These studies demonstrate the feasibility of creating ghrelin analogs that are selective for specific activities, as well as their utility in dissecting the role of ghrelin in both normal physiology and specific pathologies.
\end{abstract}

European Journal of Endocrinology 151 S71-S75

\section{Introduction}

Growth hormone (GH) secretagogues (GHS) are synthetic, unnatural peptides and non-peptide molecules that stimulate GH secretion by acting on the GHS-1a receptor $(1,2)$. Ghrelin is a 28 amino acid, acylated peptide isolated as the endogenous ligand for the GHS-1a receptor (3). In addition to having potent GH-releasing activity, ghrelin is the first circulating hormone demonstrated to promote feeding and adiposity, and to regulate energy homeostasis following either systemic or central administration $(3-5)$. The ability of ghrelin to increase body weight is attributed to a combination of enhanced food intake, increased gastric emptying and increased food assimilation, coupled with increased GH levels that promote prompt nutrient incorporation into muscles and fat reserves (6). These qualities have fostered the concept that ghrelin may have therapeutic potential in treating diseases of malnutrition and wasting. Conversely, ghrelin antagonists may be effective in suppressing food intake and weight gain. In our efforts to create ghrelin analogs with potential therapeutic benefit, we have discovered an analog of human ghrelin (h-ghrelin), BIM28163, which binds to, but does not activate, the human GHS-1a receptor. We have subsequently demonstrated that BIM-28163 is a full, competitive antagonist of the GHS-1a receptor (7), and, as such, is a valuable tool for dissecting the physiological significance and therapeutic potential of ghrelin actions.

\section{In vitro studies}

BIM-28163 binds to the human (h) GHS-1a receptor with a dissociation constant $\left(K_{\mathrm{i}}\right)=8.1 \pm 1.4 \mathrm{nmol} / \mathrm{l}$, as compared with native h-ghrelin with a $K_{\mathrm{i}}=1.63 \pm 0.32$ $\mathrm{nmol} / \mathrm{l}$. Unlike native ghrelin, however, BIM-28163 is unable to activate the h-GHS-1a receptor as demonstrated by its inability to stimulate calcium mobilization in h-GHS-1a transfected cells. When added in combination, BIM-28163 completely and dose-dependently 
inhibits the ability of h-ghrelin to activate the h-GHS-1a receptor, indicating that BIM-28163 is a full, competitive antagonist at the h-GHS-1a receptor.

\section{In vivo effect on GH secretion}

Injection of $1 \mathrm{mg} / \mathrm{kg}$ BIM-28163 into cannulated, unanesthetized, freely-moving rats produces no significant change in $\mathrm{GH}$ secretion during the subsequent $60 \mathrm{~min}$ (Fig. 1A). In contrast, injection of $10 \mu \mathrm{g} / \mathrm{kg}$ native hghrelin results in a significant release of $\mathrm{GH}$ within 10 min of injection (Fig. 1A). When the same dose of h-ghrelin is injected into rats previously treated with BIM-28163, no significant change in GH secretion is observed, indicating that BIM-28163 effectively blocks the GH-releasing action of h-ghrelin in vivo (Fig. 1A). Previous studies have demonstrated that while there is direct pituitary interaction, the bulk of the GH-releasing action of ghrelin is mediated via the hypothalamus
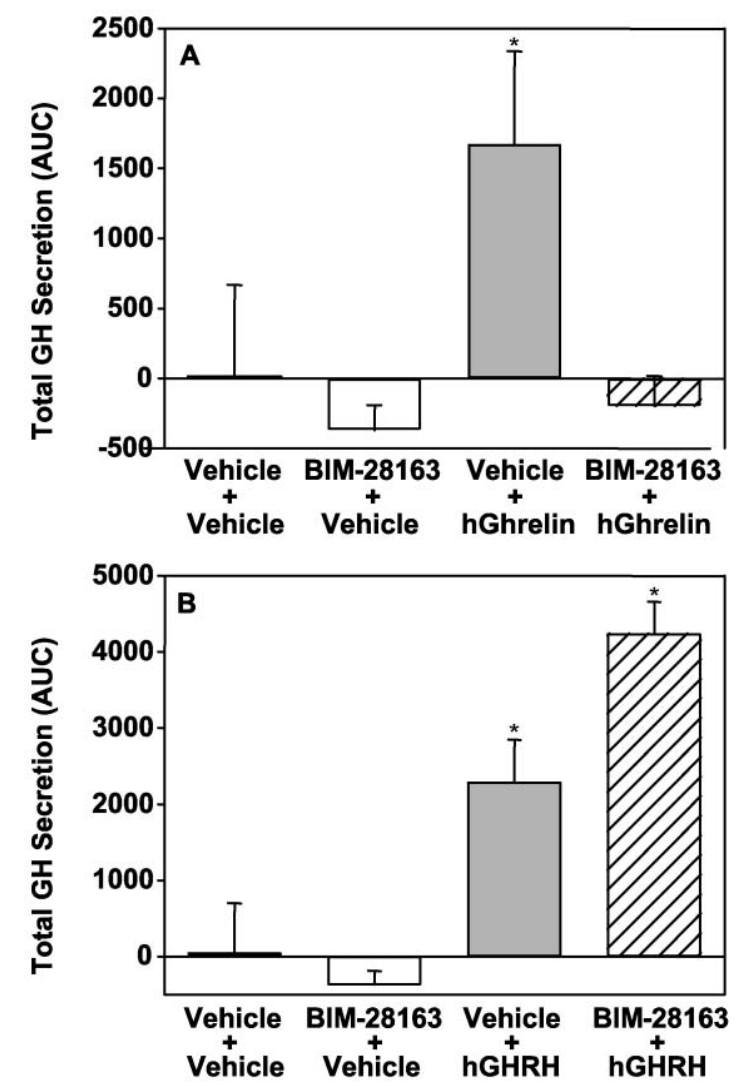

Figure 1 (A) BIM-28163 does not elicit GH secretion and completely blocks h-ghrelin-induced $\mathrm{GH}$ secretion. Rats $(n=8)$ were injected i.v. with vehicle (solid bar), BIM-28163 (open bar), h-ghrelin (gray bar) or BIM-28163 + h-ghrelin (hatched bar). (B) BIM-28163 does not inhibit GHRH-stimulated GH secretion. Rats $(n=8)$ were injected i.v. with vehicle (solid bar), BIM-28163 (open bar), GHRH (gray bar) or BIM-28163 + GHRH (hatched bar). Results are expressed as the total amount of $\mathrm{GH}$ secreted (area under the curve, AUC). Bar and brackets = means \pm S.E.M. ${ }^{\star} P<0.05$ versus vehicle-injected controls. through stimulation of GH releasing hormone (GHRH) secretion and suppression of somatostatin (8). To examine the specificity of BIM-28163 inhibition of ghrelinstimulated GH secretion, the experiment was repeated substituting GHRH in place of h-ghrelin. Like h-ghrelin, injection of $10 \mu \mathrm{g} / \mathrm{kg} \mathrm{h}-\mathrm{GHRH}(1-44)$ alone induces a significant increase in $\mathrm{GH}$ secretion within $10 \mathrm{~min}$ of injection; however, in contrast to the results obtained with ghrelin, BIM-28163 is unable to suppress the GH-releasing action of GHRH (Fig. 1B). These results demonstrate that BIM-28163 specifically antagonizes the GH-releasing action of ghrelin by preventing interaction with the GHS-1a receptor and not by interfering with the subsequent actions of GHRH. These results strongly support the prior contention that the $\mathrm{GH}$ releasing action of ghrelin is mediated through the GHS-1a receptor.

\section{In vivo effects on feeding and weight gain}

To test the possibility that BIM-28163 may also be able to block the ghrelin actions of increasing food intake and weight gain, we injected normal, male rats with either $40 \mathrm{nmol} / \mathrm{kg}$ h-ghrelin or 40 or $400 \mathrm{nmol} / \mathrm{kg}$ BIM-28163 (i.p.) three times per day for 7 days, and monitored body weight and food and water consumption. The higher dose of BIM-28163 was included due to the lower affinity of this analog for the GHS-1a receptor as compared with h-ghrelin. Treatment with h-ghrelin stimulates a significant increase in total food consumed over the 7-day period, and induces a significant, progressive increase in weight gain as compared with vehicle-treated controls (Fig. 2A and B). The $40 \mathrm{nmol} / \mathrm{kg}$ BIM-28163 treatment is without effect; however, unexpectedly, $400 \mathrm{nmol} / \mathrm{kg}$ BIM-28163 increases both food intake and body weight gain to a comparable extent as that observed with h-ghrelin (Fig. 2B). These results indicate that although BIM28163 is a full, competitive antagonist of the GHS-1a receptor, and fully blocks the ability of h-ghrelin to stimulate GH secretion in vivo, with regard to the ghrelin actions of stimulating increased food intake and weight gain, BIM-28163 is an agonist. These surprising findings suggest that the feeding and weight modulating actions of ghrelin are mediated by an, as yet, unknown receptor (9).

\section{A novel ghrelin receptor - induction of hypothalamic c-fos immunoreactivity}

To provide further clarification as to whether a novel ghrelin receptor may mediate the actions of ghrelin on feeding and weight gain, we examined the interaction of ghrelin and BIM-28163 in selected hypothalamic regions. Male rats, fitted with an indwelling right lateral ventricular cannula, were injected intracerebroventricularly (i.c.v.) with $1 \mu \mathrm{g}$ h-ghrelin, $5 \mu \mathrm{g}$ BIM-28163 

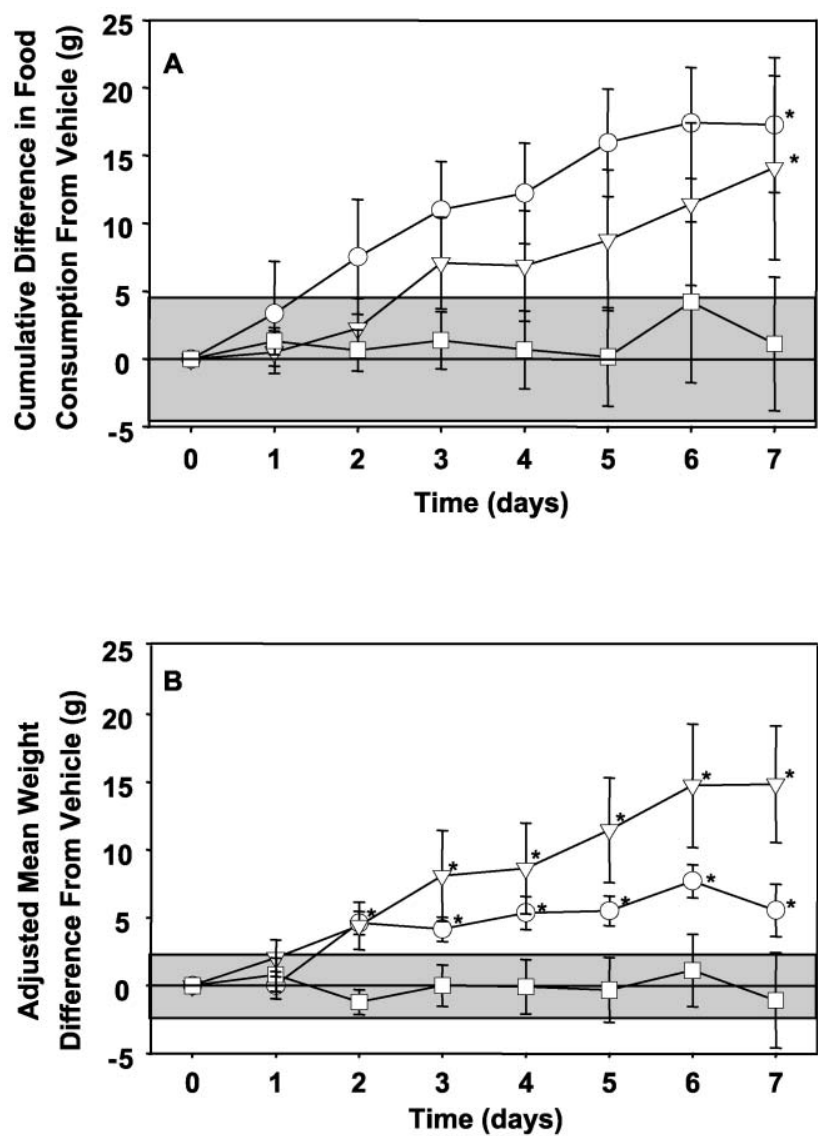

Figure 2 BIM-28163 stimulates increased cumulative food consumption (A) and body weight gain (B) at least as effectively as h-ghrelin when administered at a 10-fold higher dose. Rats $(n=8)$ were injected i.p. with $40 \mathrm{nmol} / \mathrm{kg} \mathrm{BIM-28163}$ (squares), $400 \mathrm{nmol} / \mathrm{kg} \mathrm{BIM}-28163$ (triangles) or $40 \mathrm{nmol} / \mathrm{kg} \mathrm{h}$-ghrelin (circles). Mean \pm S.E.M. values of the vehicle-treated rats are represented by the gray shaded area. Results are expressed as means \pm S. E.M. ${ }^{\star} P<0.05$ versus vehicle-treated controls.

or the combination of the two at the same doses. Ninety minutes after injection, the rats were killed by transcardial perfusion, and the brains were removed, post-fixed, sectioned and processed for Fos immunocytochemistry. Nuclear Fos protein immunoreactivity (Fos-IR) was used as a marker of neuronal activity and immunopositive cells were quantified according to previously reported methods (10).

We examined the effect of these treatments in two hypothalamic areas known to be activated by ghrelin $(11,12)$, the medial arcuate nucleus (mARC), a region known to be involved in the regulation of $\mathrm{GH}$ secretion $(13,14)$, and the dorsal medial hypothalamus $(\mathrm{DMH})$, a region known to be involved in modulation of feeding (15). Treatment with h-ghrelin significantly increases Fos-IR in both the mARC and DMH, as has previously been reported $(5,11,12)$ (Fig. 3). In contrast, BIM-28163 does not alter Fos-IR in the mARC, and, when co-injected with h-ghrelin, completely blocks the ability of h-ghrelin to increase Fos-IR in

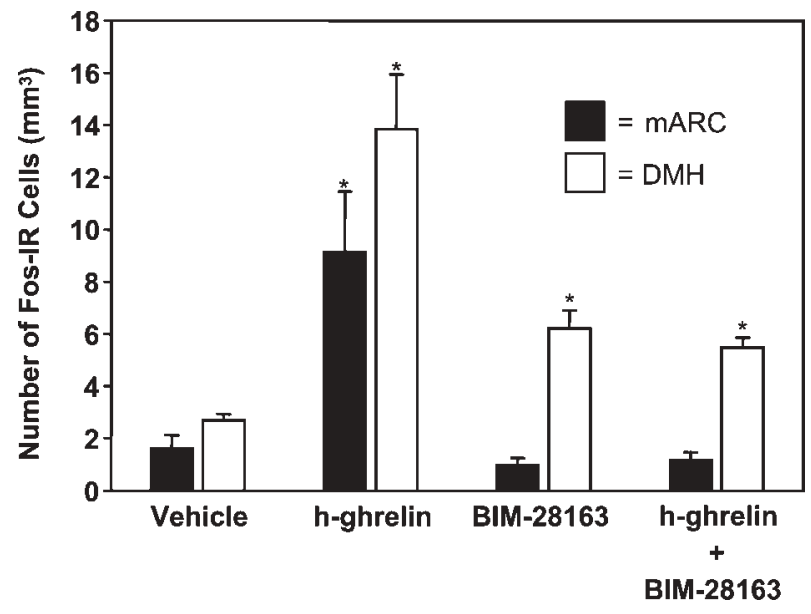

Figure 3 Induction of Fos-IR in the medial arcuate nucleus (mARC, solid bars) and dorsal medial hypothalamus (DMH, open bars) in response to i.c.v. administration of h-ghrelin $(1 \mu \mathrm{g})$ and BIM-28163 $(5 \mu \mathrm{g})$, either alone or in combination. Results are the number of Fos-IR cells in each region, and are expressed as means \pm S. E.M. ${ }^{\star} P<0.05$ versus vehicle-treated controls.

this region (Fig. 3). These results are consistent with our previous observation that BIM-28163 does not elicit GH secretion and that it blocks h-ghrelin-induced $\mathrm{GH}$ secretion. These results are also in keeping with the concept of the mARC as a key site of ghrelin action on $\mathrm{GH}$ secretion.

When the effect of BIM-28163 on the DMH was examined, it was observed that, like ghrelin, BIM28163 also significantly increases Fos-IR in this region. Even more intriguing is the observation that h-ghrelin induces a greater number of Fos-IR cells in the DMH than does BIM-28163; however, when the two are co-administered, the level of Fos-IR is the same as observed with BIM-28163 alone (Fig. 3). These results indicate that BIM-28163 induces Fos-IR in the DMH via the same receptor as h-ghrelin, and that this receptor is not GHS-1a. This observation is consistent with our finding that BIM-28163 is an agonist with regard to the ghrelin action of increasing food intake and weight gain. Previous studies have implicated the DMH as being involved in the regulation of feeding (15); however, the majority of studies to date suggest that the arcuate nucleus may be the primary site of ghrelin action on feeding (16-18). Our present findings exclude neither the arcuate nucleus as a site of ghrelin action on feeding nor the GHS-1a receptor as a modulator of this effect. The present results do, however, suggest that if the GHS-1a receptor is involved in the feeding actions of ghrelin, then the novel receptor at which BIM-28163 is an agonist is either the dominant receptor for this action or it assumes this function when the GHS-1a receptor is disabled or antagonized. In any event, the present results strongly suggest that the GHS-1a receptor may not be the appropriate target for anti-obesity/feeding therapeutics. 
A splice variant of the GHS-1a receptor with only five transmembrane domains has been described, the GHS$1 \mathrm{~b}$ receptor (2); however, GHS-1b has been demonstrated not to bind native ghrelin, and thus cannot be the novel ghrelin receptor identified in the present studies. An alternative, albeit unlikely, explanation for the observed results is that the GHS-1a receptor assumes different conformations in different locations and for different functions; thus, BIM-28163 may interact as an agonist at GHS-1a at one site and as an antagonist at another. Different conformations of GHS-1a could possibly arise as a result of altered processing in different tissues, or as a result of interaction with different receptors expressed in different tissues.

The separation of the GH-releasing and weight modulating activities of ghrelin by BIM-28163 may suggest possible mechanisms for the paradox observed in certain pathologies such as Prader-Willi syndrome in which patients have frankly elevated circulating ghrelin levels and insatiable feeding desires, but are $\mathrm{GH}$ deficient (19).

\section{Use of BIM-28163 to dissect the role of endogenous ghrelin - regulation of GH secretion}

One of the major questions surrounding the GHS concept, and now ghrelin, is that even though this pathway is clearly capable of effectively stimulating $\mathrm{GH}$ release, does it have a role in normal GH physiology? To answer this question, we have examined the effect of BIM-28163 on the pulsatile pattern of GH secretion in chronically cannulated, unanesthetized, freely-moving rats. Either BIM-28163 $(5 \mu \mathrm{g} / \mathrm{h})$ or vehicle were infused i.c.v. via an indwelling right lateral ventricular cannula for $48 \mathrm{~h}$. Blood samples were collected every $20 \mathrm{~min}$ over $7 \mathrm{~h}$ at the end of 24 and $48 \mathrm{~h}$ of infusion. The pattern of GH secretion was determined and analyzed by Cluster analysis to identify pulses and determine the pulsatile parameters. $\mathrm{GH}$ secretion is pulsatile in both the saline- and BIM28163-treated groups; however, the total and mean level of GH secretion, as well as every parameter of pulsatile GH secretion (pulse frequency, pulse amplitude and nadir level) are significantly reduced. The decreased frequency of pulses may reflect the inability of the analytical method to recognize pulses following the significant reduction in pulse amplitude rather than an actual decrease in pulse generation. These results clearly demonstrate that chronic elimination of ghrelin activity at the GHS-1a receptor in normal, adult rats significantly reduces the magnitude of pulsatile GH secretion.

It is well established that the pulsatile release of $\mathrm{GH}$ results from the interplay of hypothalamic GHRH and somatostatin acting on the pituitary somatotropes (20).
The present results indicate that endogenous ghrelin acts normally through the GHS-1a receptor to amplify this pulsatile GH signal. These data fit well with previous studies that have examined the effect of exogenously administered GHSs on GH secretion. It has been demonstrated that both the GHSs and ghrelin act synergistically with GHRH in stimulating the release of GH $(21,22)$. This finding is very much in keeping with the lowered pulse amplitude observed in the present study following inhibition of GHS-1a receptor activation. Several studies have also demonstrated that administration of GH-releasing peptides or GHSs will amplify the normal pulsatile pattern of $\mathrm{GH}$ in both young and elderly human subjects $(23,24)$. These findings are consistent with the concept that endogenous ghrelin acts through the GHS-1a receptor to amplify the normal pulsatile pattern of GH secretion.

\section{Summary and concluding remarks}

In summary, the identification of an antagonist of the GHS-1a receptor has provided an important tool for dissecting the role of the GHS-1a receptor in specific ghrelin actions. Initial studies with this compound have confirmed the role of the GHS-1a receptor in mediating the effects of ghrelin on GH secretion. Furthermore, evidence has been obtained for a role of endogenous ghrelin acting through the GHS-1a receptor to amplify the normal, pulsatile pattern of $\mathrm{GH}$ secretion. Unexpectedly, evidence for an additional ghrelin receptor that is distinct from GHS-1a and that may modulate the effects of ghrelin on food intake and weight gain has also been revealed. These findings are particularly important as they suggest that current strategies targeting the GHS-1a receptor as a means to treat obesity or to enhance feeding in cachexic states may be misguided. Elucidation of the novel ghrelin receptor demonstrated in the present studies may provide a more appropriate target.

In addition to its utility as a research tool, the present results with BIM-28163 demonstrate the feasibility of creating ghrelin-based therapeutics that are selective for specific ghrelin actions, such as either modulation of GH secretion or weight gain. Selective ghrelin modulators of feeding may prove useful in conditions in which increased $\mathrm{GH}$ and insulin-like growth factor-I secretion might be considered a disadvantage, such as cancer-related cachexia.

\section{References}

1 Bowers CY. Unnatural growth hormone-releasing peptide begets natural ghrelin. Journal of Clinical Endocrinology and Metabolism 200186 1464-1469.

2 Howard AD, Feighner SD, Cully DF, Arena JP, Liberator PA, Rosenblum CI, Hamelin M, Hreniuk DL, Palyha OC, Anderson J, Paress PS, Diaz C, Chou M, Liu KK, McKee KK, Pong S-S, Chuang L-Y, Elbrecht A, Dashkevicz M, Heavens S, Rigby M, Sirinathsinghji 
DJS, Dean DC, Melillo DG, Patchett AA, Nargund R, Griffin PR, DeMartino JA, Gupta SK, Schaeffer JM, Smith RG \& Van der Ploeg LHT. A receptor in pituitary and hypothalamus that functions in growth hormone release. Science $1996273974-977$.

3 Kojima M, Hosoda H, Date Y, Nakazato M, Matsuo H \& Kangawa $\mathrm{K}$. Ghrelin is a growth-hormone-releasing acylated peptide from stomach. Nature $1999 \mathbf{4 0 2} 656-660$.

4 Tschop M, Smiley DL \& Heiman ML. Ghrelin induces adiposity in rodents. Nature $2000 \mathbf{4 0 7} 908-913$.

5 Nakazato M, Murakami N, Date Y, Kojima M, Matsuo H, Kangawa $\mathrm{K} \&$ Matsukura S. A role for ghrelin in the central regulation of feeding. Nature $2001 \mathbf{4 0 9} 194-198$.

6 St-Pierre DH, Wang L \& Tache Y. Ghrelin: a novel player in the gut-brain regulation of growth hormone and energy balance. News in Physiological Sciences 200318 242-246.

7 Taylor JE, Dong JZ, Shen Y, De Oliveira D, Datta R \& Culler MD. Identification of a ghrelin analog that is an antagonist at the human growth hormone secretagogue (GHS) receptor. 85th Annual Meeting of the Endocrine Society 2003 Abstract P3-P92.

8 Tannenbaum GS, Epelbaum J \& Bowers CY. Interrelationship between the novel peptide ghrelin and somatostatin/growth hormone-releasing hormone in regulation of pulsatile growth hormone secretion. Endocrinology $2003 \mathbf{1 4 4} 967-974$

9 Culler MD, Dong JZ, Shen Y, Zhang J, De Oliveira D, Taylor JE \& Datta R. Dissociation of ghrelin action on GH-stimulation and weight gain. 85th Annual Meeting of the Endocrine Soceity 2003 P3-P93 Abstract.

10 Diano S, Horvath B, Urbanski HF, Sotonyi P \& Horvath T. Fasting activates the nonhuman primate hypocretin (orexin) system and its postsynaptic targets. Endocrinology $20031443774-3778$.

11 Mitchell V, Bouret S, Beauvillain JC, Schilling A, Perret M, Kordon C \& Epelbaum J. Comparative distribution of mRNA encoding the growth hormone secretagogue-receptor (GHS-R) in Microcebus murinus (Primate, lemurian) and rat forebrain and pituitary. Journal of Comparative Neurology 200115 469-489.

12 Horvath TL, Diano S, Sotonyi P, Heiman M \& Tschop M. Minireview: ghrelin and the regulation of energy balance - a hypothalamic perspective. Endocrinology $20011424163-4169$.

13 Bluet-Pajot MT, Epelbaum J, Gourdji D, Hammond C \& Kordon C. Hypothalamic and hypophyseal regulation of growth hormone secretion. Cellular and Molecular Neurobiology 199818 101-123.

14 Hewson AK, Tung LY, Connell DW, Tookman L \& Dickson SL. The rat arcuate nucleus integrates peripheral signals provided by leptin, insulin, and a ghrelin mimetic. Diabetes $2002 \mathbf{5 1}$ 3412-3419.

15 Bellinger LL \& Bernardis LL. The dorsomedial hypothalamic nucleus and its role in ingestive behavior and body weight regulation: lessons learned from lesioning studies. Physiological Behavior $200276431-442$.
16 Riediger T, Traebert M, Schmid HA, Scheel C, Lutz TA \& Scharrer E. Site-specific effects of ghrelin on the neuronal activity in the hypothalamic arcuate nucleus. Neuroscience Letters $2003 \mathbf{3 4 1}$ $151-155$.

17 Kohno D, Gao HZ, Muroya S, Kikuyama S \& Yada T. Ghrelin directly interacts with neuropeptide-Y-containing neurons in the rat arcuate nucleus: $\mathrm{Ca}^{2+}$ signaling via protein kinase $\mathrm{A}$ and N-type channel-dependent mechanisms and cross-talk with leptin and orexin. Diabetes 200352 948-956.

18 Bagnasco M, Tulipano G, Melis MR, Argiolas A, Cocchi D \& Muller EE. Endogenous ghrelin is an orexigenic peptide acting in the arcuate nucleus in response to fasting. Regulatory Peptides $2003111161-167$.

19 Cummings DE, Clement K, Purnell JQ, Vaisse C, Foster KE, Frayo RS, Schwartz MW, Basdevant A \& Weigle DS. Elevated plasma ghrelin levels in Prader Willi syndrome. Nature Medicine 20028 643-644.

20 Tannenbaum GS \& Epelbaum J. Effects of growth hormone on body composition and bone metabolism. Endocrine 200012 163-172.

21 Arvat E, Maccario M, Di Vito L, Broglio F, Benso A, Gottero C, Papotti M, Muccioli G, Dieguez C, Casanueva FF, Deghenghi R, Camanni F \& Ghigo E. Endocrine activities of ghrelin, a natural growth hormone secretagogue (GHS), in humans: comparison and interactions with hexarelin, a nonnatural peptidyl GHS, and GH-releasing hormone. Journal of Clinical Endocrinology and Metabolism 200186 1169-1174.

22 Cunha SR \& Mayo KE. Ghrelin and growth hormone (GH) secretagogues potentiate $\mathrm{GH}$-releasing hormone (GHRH)-induced cyclic adenosine $3^{\prime}, 5^{\prime}$-monophosphate production in cells expressing transfected GHRH and GH secretagogue receptors. Endocrinology 2002143 4570-4582.

23 Huhn WC, Hartman ML, Pezzoli SS \& Thorner MO. Twenty-fourhour growth hormone (GH)-releasing peptide (GHRP) infusion enhances pulsatile GH secretion and specifically attenuates the response to a subsequent GHRP bolus. Journal of Clinical Endocrinology and Metabolism $1993 \mathbf{7 6} 1202-1208$.

24 Chapman IM, Hartman ML, Pezzoli SS \& Thorner MO. Enhancement of pulsatile growth hormone secretion by continuous infusion of a growth hormone-releasing peptide mimetic, L-692,429, in older adults - a clinical research center study. Journal of Clinical Endocrinology and Metabolism $1996 \mathbf{8 1}$ 2874-2880.

Received 27 February 2004

Accepted 3 May 2004 